\title{
Response inhibition of rats with frontal ablations and caudate-putamen lesions'
}

MERLE E. MEYER

WESTERN WASHINGTON STATE COLLEGE

To investigate effects of frontal ablations or caudateputamen lesions on response inhibition, 45 food-deprived rats were trained on one of three DRL schedules. The results suggest that neither frontal ablations nor caudateputamen lesions differentially affect DRL performance when compared to sham-controls.

Rosvold (Rosvold \& Szwarcbart, 1964) has re-emphasized the role of the frontocortical area and its various associated subcortical structures in timing behavior (response inhibition and short term memory), general activity, and visual discrimination. It is, thus, suggestive that bilateral lesions in the caudate-putamen and frontal ablations could disrupt timing behavior, as measured in terms of differential reinforcement of low rate (DRL) performance, in the rat. The DRL schedule should be particularly sensitive to impairment of response inhibition in that with the DRL a pause of some specified time interval or longer must occur after the last response before the reinforcement is given.

Subjects

The Ss were 4590 day old male Sprague-Dawley rats. Fifteen received bilateral frontal ablations, 15 bilateral lesions in the head of the caudate-putamen nucleus, while 15 served as sham-operative controls. Apparafus

The apparatus consisted of two conventional operant boxes, each placed in a sound deadened chamber equipped with a circulating fan and white noise which served as an auditory mask. Standard relay equipment was used to program all reinforcement contingencies. The reinforcers were $45 \mathrm{mg}$ Noyes pellets, and were given under the contingency of one of three DRL schedules (5-sec, 10-sec, or 15-sec). The Ss' responses and reinforcements were recorded on both counters and cumulative recorders.

Operative and Histological Procedures

All surgery was in a one-stage operation under general clean conditions. The Ss were anesthetized with Nembutal and were held in a stereotaxic apparatus during surgery. Bilateral lesions for the caudate-putamen Ss were produced following a standard operative procedure. A direct current of $5 \mathrm{~mA}$ was delivered for $30 \mathrm{sec}$ through a monopolar 24 gauge nichrome cathode insulated with Formvar except at the tip. The coordinates were taken from the atlas by Konig \& Klippel (1963) and were used in conjunction with the stereotaxic instrument to achieve the placement of the lesions. The bilateral ablations for the frontal $\mathrm{Ss}$ were produced by subpial aspiration of the desired portion of the brain. The same procedure was used for the sham-operative Ss except for the actual removal of tissue. Following surgery all Ss were given intramuscular injections of penicillin.

At the conclusion of the experiment, each operated rat was sacrificed and perfused intracardially with $10 \%$ formalin. The brain was removed and frozen sections made.

\section{Conditioning}

After seven days following surgery, all Ss were placed on a 22- $\mathrm{h}$ food deprivation schedule which continued for the remainder of the study. One week later, the Ss were magazine trained and then shaped to press the response bar. Each $S$ received two days of training under a continuous reinforcement schedule (CRF), receiving 100 reinforcements a day. Five animals from each of the three treatment groups were then randomly placed on one of the three DRL schedules and continued on that schedule until the $S$ reached the final criterion performance of three successive 50-min daily sessions in which the $\mathrm{S}$ received reinforcements on at least $50 \%$ of the responses.

Anatomical Findings

All caudate-putamen lesions were verified histologically. Figure 1 illustrates approximations of the extent of the minimum and maximum lesions produced in the dorsal caudate-putamen. Reconstructions of the approximations of the areas of bilateral damage to the frontal cortex are shown in Fig. 2 with the minimum and maximum lesions to this area.

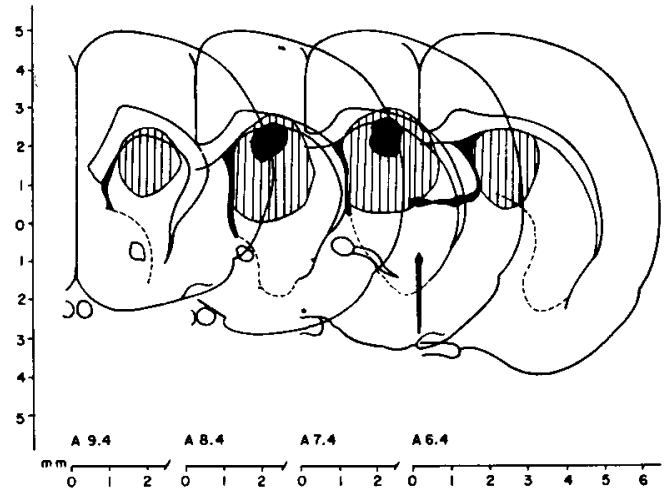

Fig. 1. Reconstruction of caudate-putamen lesions. The vertical lines illustrates the maximum and the solid areas the minimum lesions. 


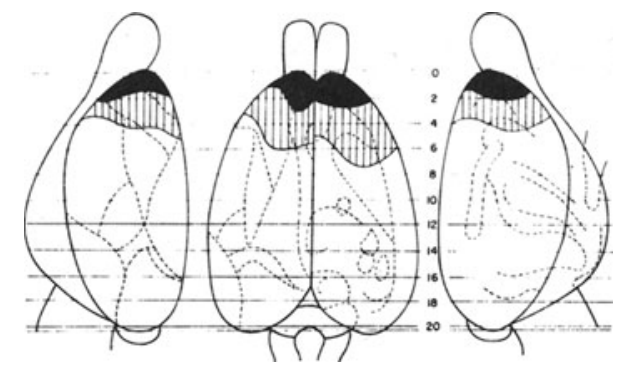

Fig. 2. Reconstruction of frontal ablations. The vertical lines illustrates the maximum and the solid areas the minimum damage.

\section{Behavioral Findings}

In general, the animals with caudate-putamen lesions and frontal ablations are harder to shape to make the bar press response than the sham-controls. Once shaped, however, the rate of response on the CRF schedule was, for the most part, as high and steady as the controls.

Table 1 presents the mean number of days required for the three treatment groups under the three DRL schedules to reach the final criterion of three successive daily sessions in which the Ss received reinforcements on at least $50 \%$ of the responses.

The differences between the treatment groups were not statistically significant $(F<1, d f=2 / 36, p>.05)$. As seen from Table 1 , the means are essentially the same between the three treatment conditions. As would be expected, marked significant differences were obtained between the three DRL schedules (F $=17.02, \mathrm{df}=2 / 36, \mathrm{p}<.001$ ), where DRL $5<$ DRL $10<$ DRL 15. The interaction between treatment groups

Table 1

\begin{tabular}{lrrr}
\multicolumn{4}{c}{ Mean number of days to criterion } \\
\hline Group & DRL & N & $\bar{X}$ \\
\hline \multirow{3}{*}{ Sham-controls } & 5 & 5 & 5.8 \\
& 10 & 5 & 8.8 \\
& 15 & 5 & 31.4 \\
\hline \multirow{3}{*}{ Caudates } & 5 & 5 & 3.4 \\
& 10 & 5 & 11.2 \\
& 15 & 5 & 23.6 \\
\hline & 5 & 5 & 3.0 \\
Frontal s & 10 & 5 & 12.4 \\
& 15 & 5 & 28.4 \\
\hline
\end{tabular}

and DRL schedules was not significant $(F<1, \mathrm{df}=4 / 36$, $p>.05)$ and thus shows no differential effects between treatment conditions and DRL schedules.

These data suggest that the aspect of response inhibition for timing behavior in the rat, as measured by three DRL schedules, is not affected by either frontal cortex damage or by lesions in the caudateputamen, in terms of days to reach the final criterion. This suggests that other neural structures mediate timing behavior in rats. Two such structures are the septum and the hippocampus. Ellen, Wilson, \& Powell (1964) found that septal lesions disrupted the rat's DRL behavior and Burkett \& Bunnell (1967) report that septal lesions impaired the rates on a DRL schedule after the Ss had obtained a stable response rate. Comparable findings have been reported by Clark \& Isaacson (1965), and by Schmaltz \& Isaacson (1966), which show that very marked bilateral hippocampal ablations have major effects upon DRL performance. The above findings and these latter reports suggest that various neural structures of the limbic system may be involved in timing behavior of rats rather than the frontocortical area and its associated subcortical structures.

\section{References}

Burkett, E. E., \& Bunnell, B. N. Septal lesions and the retention of DRL performance in the rat. J. comp. physiol. Psychol., $1967,62,468-471$.

Clark, C. V., \& Isaacson, R. L. Effects of bilateral hippocampal ablation on DRL performance. J. comp. physiol. Psychol., 1965 , $59,137-140$.

Ellen, P., Wilson, A. S., \& Powell, E. W. Septal inhibition and timing behavior in the rat. Experimental Neurology, 1964, 10, 120-132.

Konig, J. F. R., \& Klippel, R. A. The rat brain: a stereotaxic atlas. Baltimore: The Williams and Wilkins Co., 1963.

Rosvold, H. E., \& Szwarcbart, M. K. Neural structures involved in delayed-response performance. In J. M. Warren \& K. Akert (Eds.), The frontal granular cortex and behavior. New York: MCGraw-Hill Book Co., 1964. Pp. 1-15.

Schmaltz, L. W., \& Isaacson, R. L. Retention of a DRL 20 schedule by hippocampectormized and partially neodecorticate rats. $J$. comp. physiol. Psychol., 1966, 62, 128-132.

\section{Note}

1. This research was supported in part by a Science Research Corporation grant to whitman College. Special acknowledgements are given to Charles S. Butler and John L. Santa for their work at various stages of this research. 